\title{
Effectiveness of group counseling services using self management techniques on aggressive student behavior
}

\section{Rita Novita ${ }^{1}$, Neviyarni ${ }^{2}$}

${ }^{1}$ Universitas Negeri Padang, ${ }^{2}$ Universitas Negeri Padang

${ }^{*}$ Corresponding author, e-mail: ritanovitajamal@gmail.com

\begin{abstract}
Aggressive behavior is behavior that aims to hurt and injure others physically and psychologically. The factors that influence the occurrence of aggressive behavior are the influence of the student's environment and violent broadcasts on television and social media (Facebook, Instagram, WhatsApp, Telegram and so on). So that efforts are needed to reduce aggressive behavior in students. The aggressive behavior that occurs is physical aggressive behavior, verbal aggressive behavior, excessive angry excessive hostile behavior and behavior. One of the efforts made to reduce students' aggressive behavior at school is to carry out group counseling services with self-management techniques, where the sample in this study was 15 people divided into an experimental group of 8 students and 7 students in the control group. using a non-test instrument, namely a questionnaire. this study aims to test the effectiveness of group counseling services using self-management techniques to reduce aggressive behavior. The findings of this study are: (1) there is a significant difference in the aggressive behavior of the experimental group before and after following self-management techniques (2) there is a significant difference in the aggressive behavior of the control group before and after being given group counseling services about aggressive behavior without special treatment, (3) ) There is a difference in the aggressive behavior of the experimental group students who were given group self-management techniques with the control group who were given group counseling services about aggressive behavior without special treatment, this can be seen in the post-test average score of the experimental group falling higher than the average postest score. control group.
\end{abstract}

Keywords: Aggressive behavior, self management techniques, group counseling

How to Cite: Novita, R., Neviyarni, N. (2021). Effectiveness of group counseling services using self management techniques on aggressive student behavior. International Journal of Applied Counseling and Social Sciences, 2 (2): pp. 140-146, DOI: http://doi.org/10.24036/005427ijaccs 


\section{Introduction}

The rise of violent incidents among students in various parts of Indonesia has made headlines in various media, both print and social media. Violence that is committed often occurs at school and outside of school. The form of violence that occurs in schools is the presence of aggressive student behavior, both students and students and it does not rule out the possibility of students being aggressive towards teachers as we know that aggressive behavior is behavior that aims to hurt other people both physically and verbally, active or passive. as well as directly or indirectly. The results of the International Center for Research on Women (ICRW) survey released by KPAI in February 2017 showed that 84 percent of students in Indonesia experienced violence at school. Then in the period from July to November 2017, KPAI said that it had handled around 34\% of cases related to violence in schools (Wahyu Eka Setyawan, 2018).

Data from the Indonesian Child Protection Commission (KPAI) sees violence against children in education this year is quite increasing. KPAI Commissioner for Education Retno Listyarti said out of a total of 445 cases in the education sector so far this year, 51.20 percent or 228 cases consisted of physical violence and sexual violence which was often perpetrated by educators, school principals and also by students (Intan, 2018). Data from the Head of Criminal and Criminal Investigation Unit of the Padang Police said that on April 26, 2020, there were 80 teenagers, 2 of which were women who carried out brawls and illegal races. They were herded to the Padang Police Headquarters for further guidance (Irwanda Saputra, 2020).

Information from the counseling teacher at SMA Negeri 6 Padang that there are several factors that cause aggressive behavior in SMA Negeri 6 Padang, namely the influence of cellphones and television media and social media which greatly influence the aggressive behavior of students at SMA Negeri 6 Padang, besides the influence of the environment where students live and peer influence is also a factor in the occurrence of aggressive behavior. There was even aggressive behavior which was categorized as severe, namely the existence of a fight which triggered beatings between students which resulted in one of the students being physically injured (bruised / swollen).

Based on some of these data, it can show that one of the problems that arise by SMA Negeri 6 Padang students is aggressive behavior. Yeni Karneli, Firman, Netrawati (2018) explains that aggressive behavior is physical or verbal behavior that aims to damage or injure others. Aggressive behavior is an action that causes others to suffer, causing both physical and psychological pressure. The impact of this aggressive behavior is very large on others, therefore researchers are very interested in providing group counseling services using selfmanagement techniques. We all know that everyone must have feelings of anger, so that in aggressive behavior, good self-control is needed to avoid aggressive behavior. As stated (Goleman, 2016) One of the factors that cause aggressive behavior in adolescence is biological factors such as (genes, blood chemistry, brain system), storage, learning roles, models of violence, and incorrect playing processes. Anantasari (2006) explains that the factors that cause aggressive behavior are frustration, stress, provocation and alcohol (Marcus, 2007). Aggressive includes physical violence, such as hitting, slapping, kicking, pushing, fighting, and so on. Non-verbal aggressiveness is the use of rude, disrespectful, mocking, slanderous words and profanity (Agustin, 2015). Furthermore, according to Yeni Karneli, Neviyarni \& Yulidar (2018) aggressive behavior is physical or verbal behavior that is intended to damage or injure others, which causes others to experience suffering, thus causing both physical and psychological 
distress. Yoshi bless and Yusri (2013), this aggressive behavior is not only done by students against their friends, but also towards teachers such as fighting and mocking the teacher when studying.

Based on the above opinions, it can be concluded that aggressive actions can hurt and harm others both verbally (yelling, taunting, shouting, insulting) and physically (stepping on the feet, hitting the table) and the contributing factors can also be from various causes such as stress, frustration, booze and others.

The various problems experienced by students in the school counseling teacher provide services that are in accordance with student behavior that occurs in school. The provision of guidance and counseling services is intended so that students can manifest themselves as individuals who are independent, responsible, creative students and productive workers (Hadi et al., 2013)

Efforts that can be made by counseling teachers on this aggressive behavior are to provide group counseling services. Group counseling services are one of the counseling services that are useful and strategic in helping children who face personal problems by using group thinking contributions to overcome personal problems (Siahan \& Neviyarni, Yeni Karneli, 2020).

Group counseling services can be held anywhere, indoors or outdoors, at school or outside of school. Wherever this group counseling service is carried out, it must be guaranteed that group dynamics can develop as well as possible (Prayitno, 2012). BK students and teachers can determine the place where BK services will be implemented according to mutual agreement. Group counseling can reduce aggressive behavior, by doing group counseling can form positive attitudes or behaviors. Positive attitudes that are formed in students will also lead to positive behavior, both of which can be created if students have a positive perspective, response and assessment of other people or certain objects around them and the events they experience (Sari, 2017).

Through the implementation of this group counseling service it is hoped that it can solve the aggressive problems felt by students at SMA Negeri 6 Padang. The implementation of group counseling services has been carried out by BK teachers but did not use special techniques where here the researcher offers special techniques to reduce the aggressive behavior of students in SMA Negeri 6. padang, namely self management techniques.

Self management is a process of changing the "totality of the self" from an intellectual, emotional, spiritual, and physical perspective so that what we want is achieved. High school students can recognize and understand themselves or their potential and make changes in various aspects both intellectual, emotional, spiritual, and physical towards a better direction, and manage them well and can find self-opportunities (Amaliasari \& Zulfiana, 2018). The advantages of this self-management technique for aggressive behavior are as follows: (1) students are able to responsibly manage their own behavior; (2) students are able to evaluate their own behavior without the need to compare with other people's behavior; (3) The best arrangement is self-regulation; (4) There is no need to emphasize the intensity and monitoring of the counselor / guidance counselor (Amin Zakki Nurul, 2017).

Charlton (2016) argues that there is a need for self-awareness and good self-management of themselves (adolescents), so that they are able to control their emotions and regulate themselves, not behave rudely, talk dirty or behave aggressively. Self management is a procedure in which individuals regulate their own behavior. 
Trost, S.G., \& Hutley (2015) define self management as a technique for managing individual behavior that aims to direct and manage themselves so that they can achieve independence and live productively. Self-management strategies, where students use cognitive selfmanagement strategies and behaviors associated with participating in physical activity, for example, goal setting and positive self-reinforcement.

Fitri (2013) explains that self management is a strategy used by students to control the factors that affect the learning process, namely behavioral strategies (time management and regulation) of the physical and social environment, motivation strategies to set goals and regulate emotions, learning strategies and learning methods. Suwardani, N.K.P., Dharsana, I.K., \& Suranata (2014) define self-management as a form of individual behavior that aims to direct and manage themselves in order to achieve independence and live productively. Cormier \& Nurius (2003) explain that self management is a process in which individuals direct their own behavior changes.

Based on this explanation, self management is an ability with respect to students and their skills where the student directs his behavior change from bad to better behavior so that the importance of applying self-management techniques in group counseling is to reduce aggressive behavior in students.

\section{Method}

This study uses quantitative methods. This type of research is a Quasi Experiment with the design of The Non-Equivalent Control Group. The population of this study were students of SMA Negeri 6 Padang and the samples were taken using purposive sampling technique. The research instrument used a non-test instrument in the form of a questionnaire that was judged by 3 validators. Many Instrument Statements that will be distributed to students are 24 statements, the 24 statement items are many items that are valid after being judged. Hair (in Iskandar, 2009: 95) states that the Cronbach Alpha reliability value is a measuring instrument in conducting research with a value of 0.60 so that 0.70 is the lowest acceptable value. In the aggressive behavior instrument, the rcount is 0.708 . Thus, it can be concluded that the value of rcount is greater than 0.70 so it can be said that the aggressive behavior research instrument is "Reliable". In this study using a Likert scale model, the data were analyzed using the Wilcoxon Signed Ranks Test and the Kolmogorov-Smirnov Two Independent Samples with the help of the SPSS version. 20.

\section{Results and Discussion}

The results of research that have been carried out at SMA N 6 Padang. A total of 15 students of class XI IPS were divided into the experimental group as many as 8 people and the control group as many as 7 people. Specifically, this study is to determine the effectiveness of group counseling services using self-management techniques to reduce student aggressive behavior. The data obtained are the results of the pretest and posttest related to aggressive behavior. Descriptive data was carried out in each research group (control group and experimental group). In the following, the researcher presents the results of research on the effectiveness of group counseling services using self-management techniques to reduce students' aggressive behavior. 
Table 1. Pretest and Posttest Results of the Experimental Group's Aggressive Behavior

\begin{tabular}{lllccc}
\hline \multirow{2}{*}{ Skor } & \multirow{2}{*}{ Category } & \multicolumn{2}{c}{ Pretest } & \multicolumn{2}{c}{ Posttest } \\
\cline { 3 - 6 } & & F & \% & F & $\%$ \\
\hline $\mathbf{1 0 0}$ & Very high & 0 & 0 & 0 & 0 \\
$\mathbf{8 1 - 9 9}$ & High & 5 & 63 & 0 & 0 \\
$\mathbf{6 2 - 8 0}$ & Moderate & 3 & 38 & 1 & 13 \\
$\mathbf{4 3 - 6 1}$ & Low & 0 & 0 & 3 & 38 \\
$\mathbf{4}$ & Very low & 0 & 0 & 4 & 50 \\
Quantity & & 8 & 100 & 8 & 100 \\
\hline
\end{tabular}

Based on the table above, it can be seen that there are differences in aggressive behavior in the experimental group before and after participating in group counseling services using selfmanagement techniques. Students at the time of the pretest were in the high category as many as $63 \%$ ( 5 students) and the moderate category as much as 38\% (3 students) After being given the treatment there was a change which can be seen from the posttest results as much as $13 \%$ ( 1 student) in the moderate category , 38\% (3 students) are in the low category, and 50\% (4 students) are in the very low category. It can be seen that 8 members of the experimental group who were involved in the calculation, experienced a decrease in scores from the pretest and posttest or experienced changes after being given self management techniques.

Table 2 Pretest and Posttest Results of Control Group Aggressive Behavior

\begin{tabular}{llcccc}
\hline \multirow{2}{*}{ Skor } & \multirow{2}{*}{ Category } & \multicolumn{2}{c}{ Pretest } & \multicolumn{2}{c}{ Posttest } \\
\cline { 3 - 6 } & & F & \% & F & \% \\
\hline $\mathbf{2 1 0 0}$ & Very high & 0 & 0 & 0 & 0 \\
$\mathbf{8 1 - 9 9}$ & High & 2 & 29 & 0 & 0 \\
$\mathbf{6 2 - 8 0}$ & Moderate & 5 & 71 & 1 & 14 \\
$\mathbf{4 3 - 6 1}$ & Low & 0 & 0 & 4 & 57 \\
$\mathbf{4 4 2}$ & Very low & 0 & 0 & 2 & 29 \\
Quantity & & 7 & 100 & 7 & 100 \\
\hline
\end{tabular}

Based on the table above, it can be seen that there are differences in aggressive behavior in the control group before and after being given information about aggressive behavior without special treatment. Students at the time of the pretest were $29 \%$ high ( 2 students) and the medium category was $71 \%$ (5 students). students who are in the low category are $57 \%$ (4 students) and $29 \%$ in the very low category (2 0rang students). It can be seen that 7 members of the control group who were involved in the calculation, experienced a decrease in the average number of scores from the pretest and posttest or experienced changes after being given group counseling services regarding aggressive behavior without special treatment.

Based on the data above, it can be seen that there are differences in aggressive behavior before and after being given information about aggressive behavior in both the control group and the experimental group. We can see that providing group counseling services using self- 
management techniques is more effective in reducing students' aggressive behavior compared to only group counseling services, specifically in reducing aggressive behavior.

\section{Conclusions}

Based on the research results obtained, it can be argued that in general group counseling services with self-management techniques can reduce students' aggressive behavior, whereas in particular there is a decrease in the average pretest and posttest mean score of the experimental group's aggressive behavior, this happens because students are active. carry out group counseling using management techniques, so it is necessary to carry out group counseling services using self-management techniques. In addition, there was also a decrease in the average pretest score and the average posttest score for the aggressive behavior of the control group students, this happened because the information provided was interesting for students, so an effort is needed to implement group counseling services using selfmanagement techniques to reduce aggressive behavior of students and aggressive behavior of experimental group students who were given treatment group counseling services using selfmanagement techniques with the control group being given group counseling services about aggressive behavior without special treatment, this can be seen in the post-test average score of the experimental group decreased higher than the mean score of the post control group.

Based on the above, it can be ignored that this study proves that group counseling services with self-management techniques can reduce students' aggressive behavior. The decline in group counseling scores with self-management techniques shows aggressive behavior more than just providing group counseling services about aggressive behavior without special treatment. This can be seen from the decrease in scores obtained by the experimental group who provided group counseling services with self-management techniques which were higher than the control group which was only given group services regarding aggressive behavior without special treatment.

\section{References}

Agustin, Y. (2015). Bimbingan Dan Konseling Islam Dengan Teknik Modelling Melalui Sikap Peduli Dalam Menangani Perilaku Agresif Anak Di Desa Ketegan Tanggulangin-Sidoarjo. Uin Sunan Ampel.

Amaliasari, R. D., \& Zulfiana, U. (2018). Hubungan antara Self Management dengan Perilaku Agresi pada Siswa SMA Cognicia Cognicia.

Anantasari. (2006). Menyikapi Perilaku Agresif Anak. Kanisius.

Charlton, C. . (2016). Effects of a self-management procedure using student feedback on staff members' use of praise in an out-of-school time program.

Cormier, W. H. dan C. L. . (1985). Interviewing Strategis For Helpers. (Monterey). Publishing Company.

Fitri, A. D. (2013). Penerapan Stategi Pengelolaan Diri (Self-Management) untuk Mengurangi Perilaku Konsumtif Pada Siswa Kelas X-11 SMAN 15 Surabaya. Jurnal Bimbingan Dan Konseling.

Goleman, D. (2006). Social Intelligence: Ilmu Baru Tentang Hubungan Antar Manusia.

Hadi, M. F. Z., Yusuf, A. M., \& Syahniar. (2013). Pemahaman Konselor Sekolah tentang Tugas Perkembangan Siswa dan Layanan yang Diberikan. Konselor, 2(1), 43-52. 
https://doi.org/10.24036/0201321733-0-00

Intan. (2018). Angka kekerasan di dunia didominasi agresif. Retrieved from https://www.fimela.com/lifestyle-relationship/read/3896222/kpai-mencatat-angkakekerasan-di-dunia-pendidikan-didominasi-bullying. Diakses tanggal 22 November jam 13.50 .

Irwanda Saputra. (2020, April). Balap Liar dan Tawuran Saat PSBB, 80 Remaja di Padang Ditangkap Polisi. https://langgam.id/balap-liar-dan-tawuran-saat-psbb-80-remaja-dipadang-ditangkap-polisi/ diakses pada tanggal 21 Februari pukul 02.46 wib.

Marcus, R. . (2007). Aggresion and Violence in Adolescence.

Prayitno. (2012). Jenis Layanan dan Kegiatan Pendukung Konseling. Universitas Negeri Padang.

Sari, A. E. dan R. K. (2017). PENGARUH LAYANAN BIMBINGAN KELOMPOK TERHADAP PERILAKU AGRESIF PADA SISWA. Volume 4 N. https://fip.ikipmataram.ac.id/wpcontent/uploads/2015/03/Ani-Endriani-dan-Rohana-Komala-Sari_

Siahan, D. N. A., \& Neviyarni, Yeni Karneli, N. (2020). Jurnal pendidikan dan. 2859(2), 197-203.

Suwardani, N.K.P., Dharsana, I.K., \& Suranata, K. (2014). Penerapan konseling behavioral dengan teknik self management untuk meningkatkan konsep diri siswa kelas viii b3 smp negeri 4 singaraja. Jurnal Ilmiah Bimbingan Konseling Undiksha, 2(1).

Trost, S.G., \& Hutley, J. (2015). Use of physical activity self-management strategies by high school students. Pediatric exercise science,

Wahyu Eka Setyawan. (2018, February). Memahami Akar Kekerasan di Sekolah. https://news.detik.com/kolom/d-3854794/memahami-akar-kekerasan-di-sekolah

Yeni Karneli, Firman, N. (2018). Upaya Guru Bk/Konselor Untuk Menurunkan Perilaku Agresif Siswa Dengan Menggunakan Konseling Kreatif Dalam Bingkai Modifikasi Kognitif Perilaku. Pedagogi: Jurnal Ilmu Pendidikan, 18(2), 32 https://doi.org/10.24036/fip.100.v18i2.430.000-000

Yeni Karneli, N. \& Y. (2018). Pengembangan Modul Konseling Kreatif Dalam Bingkai Kognitif Perilaku Untuk Menurunkan Perilaku Agresif Siswa. 2-5. http://repository.unp.ac.id/22089/1/1_104 lapakh_LAPORANHASILPENELITIANye ni merged.pdf

Yoshi restu dan Yusri. (2013). STUDI TENTANG PERILAKU AGRESIF SISWA DI SEKOLAH. Jurnal Ilmiah Konseling, Volume 2 N, Halaman 243-249. http://ejournal.unp.ac.id/index.php/konselor/article/view/1074/932

Zaki Nurul Amin. (2017). Portofolio Teknik-teknik Konseling (Teori dan Contoh Aplikasi Penerapan). Universitas Negeri Semarang (UNNES). 